\title{
Alterações histológicas da pars esophagea de suínos e sua relação com Helicobacter spp.
}

\author{
[Histological findings in swine pars esophagea and its Helicobacter spp. relationship]

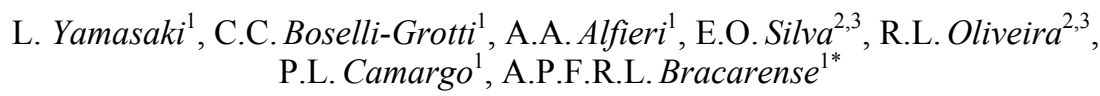 \\ ${ }^{1}$ Departamento de Medicina Veterinária Preventiva - UEL \\ Rod. Celso Garcia Cid, Km 379 \\ 86051-990 - Londrina, PR \\ ${ }^{2}$ Aluno de graduação - UEL - Londrina, PR \\ ${ }^{3}$ Bolsistas de IC-PIBIC-CNPq
}

\begin{abstract}
RESUMO
A relação entre Helicobacter spp. e a presença de alterações histológicas na pars esophagea de suínos foi avaliada em 67 estômagos de animais em idade de abate. Para a identificação das helicobactérias, utilizou-se a técnica da PCR com primers específicos para o gênero Helicobacter. As alterações histológicas foram identificadas e classificadas como ulceração, erosão, degeneração epitelial, alongamento de papilas, hiperplasia, paraqueratose, intensidade do infiltrado inflamatório e aumento do número de folículos linfoides. As alterações mais frequentemente encontradas na pars esophagea foram a degeneração epitelial e o alongamento de papilas, observadas em 83,5\% $(n=56)$ das amostras analisadas. Em 77,5\% (n=52) das amostras, observou-se paraqueratose e em 61,1\% $(n=41)$ hiperplasia epitelial. Quarenta e sete $(70,1 \%)$ foram positivas na PCR para Helicobacter spp. Nessas amostras a erosão foi a lesão mais observada (40,2\%), seguida de ulceração da mucosa (11,9\%). Em 58,2\% das amostras positivas na PCR, não foram observadas ulcerações de mucosa. Observou-se associação significativa $(\mathrm{P}=0,003)$ entre a presença de Helicobacter spp. e a degeneração epitelial da pars esophagea de suínos em idade de abate.
\end{abstract}

Palavras-chave: suíno, estômago, úlcera gástrica, Helicobacter spp., PCR

\begin{abstract}
The association between histological findings of gastric mucosa in pigs at slaughtering age and the presence of Helicobacter spp., identified by PCR, assay was investigated. Stomachs from 67 pigs were examined. Histological changes of pars esophagea were identified and classified as gastric ulcers, erosion, degeneration, distortion of papils, hyperplasia, paraqueratosis, and number of lymphoid follicles. Microscopic analysis revealed the most frequent alteration: $83.5 \%(n=56)$ stomachs with epithelial degeneration and distortion of papils. Paraqueratosis of pars esophagea was observed in $77.5 \%$ $(n=52)$ of the samples and epithelial hyperplasia in $61 \%(n=41)$. Forty-seven $(70.1 \%)$ pigs were positive to Helycobacter spp. by PCR. Erosion of pars esophagea and ulceration were the most frequent findings in Helicobacter spp. PCR-positive pigs, occurring, respectively, in $40.2 \%$ and $11.9 \%$. The frequency of animals without ulceration and Helicobacter spp. PCR-positive was $58.2 \%$. It was observed a significant association $(P=0.003)$ between Helicobacter spp. and epithelial degeneration of gastric mucosa in pigs at slaughtering age.
\end{abstract}

Keywords: swine, stomach, gastric ulcers, Helicobacter spp., PCR

Recebido em 16 de junho de 2008

Aceito em 20 de março de 2009

*Autor para correspondência (corresponding author)

E-mail: leyamasaki@sercomtel.com.br

Apoio: CNPq (Proc. 475577/04-3) 


\section{INTRODUÇÃO}

As paraqueratoses e as ulcerações da pars esophagea do estômago são lesões comuns descritas em suínos de todo o mundo. Os suínos acometidos apresentam sinais de anorexia, anemia crônica, decréscimo no ganho de peso, gastrite hemorrágica aguda e morte súbita (O’Brien, 1993; Guise et al., 1997; Roosendaal et al., 2000). As doenças gástricas são caracterizadas por diferentes graus de lesão do epitélio estratificado, podendo estender-se pelas camadas adjacentes do estômago (Morés et al., 2000). As demais alterações de pars esophagea podem variar de discreta paraqueratose a graus intensos de degeneração, hiperplasia e erosão (Embaye et al., 1990). Yamasaki et al. (2006), estudando suínos em idade de abate, observaram que a ocorrência de lesões macroscópicas, como erosões e úlceras na pars esophagea, foi de $44,1 \%$, sendo que à análise estatística não se evidenciou influência da presença de lesões gástricas sobre o peso médio da carcaça.

Helicobacter pylori foi a primeira espécie de bactéria a ser identificada colonizando o estômago de seres humanos e foi associado a gastrites e úlceras (Marshal e Warren, 1984), sendo que a infecção é condição essencial para o desenvolvimento de câncer gástrico (Brenner et al., 2004). Mais recentemente, diferentes espécies de Helicobacter foram identificadas na mucosa gástrica de diversas espécies animais com ou sem doenças gástricas (Queiroz et al., 1996; Park et al., 2003; Moutinho et al., 2007). As bactérias do gênero Helicobacter são espiraladas, curvas ou ocasionalmente cocoides, Gram negativas e habitam as glândulas, as células parietais e o muco da mucosa gástrica (Fox e Lee, 1997).

Em animais, a associação entre a presença de Helicobacter spp. e doenças gástricas, como úlceras e erosões, é controversa. Há relatos que demonstram associação positiva entre as lesões gástricas e Helicobacter spp. (Barbosa et al., 1995; Young et al., 2001; Mall et al., 2004) enquanto em outros essa relação é inconsistente (Melnichouk et al., 1999; Krakowka et al., 2005; Szeredi et al., 2005). Em cães, há um estudo recente de prevalência de helicobactérias e alterações na mucosa gástrica de animais saudáveis (Moutinho et al., 2007).
A taxa de infecção por Helicobacter spp. em suínos difere conforme o método de diagnóstico utilizado, bem como a área do estômago analisada, variando de 8,0\% a 80,0\% (Queiroz et al., 1990; De Groote et al., 2000; Park et al., 2004). Utilizando a impregnação argêntica, Yamasaki et al. (2006) observaram bactérias de formato espiralado em $47,5 \%$ dos estômagos de suínos em idade de abate, não havendo relação entre a lesão macroscópica de pars esophagea e Helicobacter spp.

O objetivo desse estudo foi verificar a ocorrência de alterações histológicas na pars esophagea de suínos em idade de abate e a sua relação com a presença de Helicobacter spp.

\section{MATERIAL E MÉTODOS}

Foram analisados 67 estômagos de suínos em idade de abate, provenientes de municípios do Estado do Paraná, abatidos em frigorífico com Serviço de Inspeção Federal.

Após a abertura do estômago pela curvatura maior, fragmentos da pars esophagea foram colhidos e fixados em solução tamponada de formalina a $10 \%$, sendo então submetidos ao processamento de rotina. Os cortes com $4 \mu \mathrm{m}$ de espessura foram corados pelo método de hematoxilina e eosina (HE) para exame histológico conforme procedimento padrão.

As alterações histológicas foram identificadas e classificadas em presença ou ausência de ulceração e/ou erosão. As alterações de alongamento de papilas, degeneração epitelial, paraqueratose e hiperplasia foram classificadas em ausência, lesão discreta e lesão grave. A análise do infiltrado inflamatório foi realizada com objetiva de 40x em três diferentes campos e a sua intensidade graduada em 0 (até 4 células/campo); 1 (5 a 15 células/campo); 2 (16 a 25 células/campo) e 3 (mais de 25 células/campo). A contagem de folículos linfoides foi realizada em objetiva de $10 \mathrm{x}$ e classificada em ausência; até dois folículos por campo; e em três ou mais folículos linfoides por campo observado. Outras alterações, como a presença de tecido de granulação e micro pústulas, quando observadas, foram também utilizadas como parâmetros nas análises relativas à presença ou ausência de Helicobacter spp. 
Para a extração do DNA, foi empregada uma associação das técnicas do fenol/clorofórmio/álcool isoamílico e da sílica/tiocianato de guanidina (Boom et al., 1990). Ao final, o DNA foi eluído em $50 \mu \mathrm{L}$ de água ultrapura estéril. Em todos os procedimentos foi incluída, como controle negativo, alíquota de água ultrapura estéril. Todas as amostras foram mantidas a $-20^{\circ} \mathrm{C}$ até a sua utilização na técnica da PCR.

A PCR foi realizada em uma solução contendo $5 \mu \mathrm{L}$ de DNA extraído e $45 \mu \mathrm{L}$ de PCR-MIX constituído por $20 \mathrm{pmol}$ de cada primer $(\mathrm{H} 276 \mathrm{f}$ e H676r; Riley et al., 1996), 0,1mM de cada dNTP, 2,5 unidades de Taq platinum DNA polimerase 1xPCR buffer $(20 \mathrm{mM}$ Tris- $\mathrm{HCl} \mathrm{pH}$ $8,4$ e $50 \mathrm{mM}$ de $\mathrm{KCl}), 1,5 \mathrm{mM} \mathrm{MgCl}_{2}$ e água ultrapura estéril para volume final de $50 \mu \mathrm{L}$. A amplificação foi realizada em termociclador nas seguintes condições de tempo e temperatura: i) uma etapa de $1 \mathrm{~min} / 94^{\circ} \mathrm{C}$; ii) 35 ciclos de $1 \mathrm{~min} / 94^{\circ} \mathrm{C}, 2 \mathrm{~min} / 59^{\circ} \mathrm{C}$ e $1 \mathrm{~min} / 72^{\circ} \mathrm{C}$ e iii) uma etapa de extensão final por $7 \mathrm{~min} / 72^{\circ} \mathrm{C}$.

Alíquotas com $10 \mu \mathrm{L}$ dos produtos da PCR foram submetidas à eletroforese em gel de agarose a $2 \%$ com brometo de etídeo $(0,5 \mu \mathrm{L} / \mathrm{mL})$ em tampão TBE pH 8.4 (89mM TRIS, $89 \mathrm{mM}$ ácido bórico, $2 \mathrm{mM}$ EDTA), sob voltagem constante
$(90 \mathrm{~V})$ durante aproximadamente $30 \mathrm{~min}$. O gel foi visualizado sob luz ultravioleta (UV) e fotodocumentado em sistema digital ${ }^{1}$.

A análise estatística foi realizada a partir dos percentuais de ocorrência de bactérias nos grupos com e sem lesão gástrica, que foram comparados pelo teste do qui-quadrado ou pelo teste exato de Fisher com nível de significância de 5\%.

\section{RESULTADOS}

As alterações histológicas mais frequentes foram a degeneração epitelial e o alongamento de papilas, identificadas em $56(83,5 \%)$ amostras analisadas (Tab. 1). Em 52 (77,6\%) amostras, verificou-se paraqueratose e em 41 (61,1\%), hiperplasia epitelial. Lesões graves de paraqueratose e alongamento de papilas epiteliais (Fig. 1) foram observados em $24(35,8 \%)$ e 25(37,3\%) amostras, respectivamente (Tab. 1).

As erosões de epitélio (Fig. 2A) foram verificadas em $40(59,7 \%)$ amostras, enquanto a ulceração da pars esophagea foi identificada em $12(17,9 \%)$, nas quais se notou acentuado infiltrado inflamatório misto ou mononuclear (Fig. 2B). Em três dessas 12 amostras, verificouse, também, tecido de granulação.

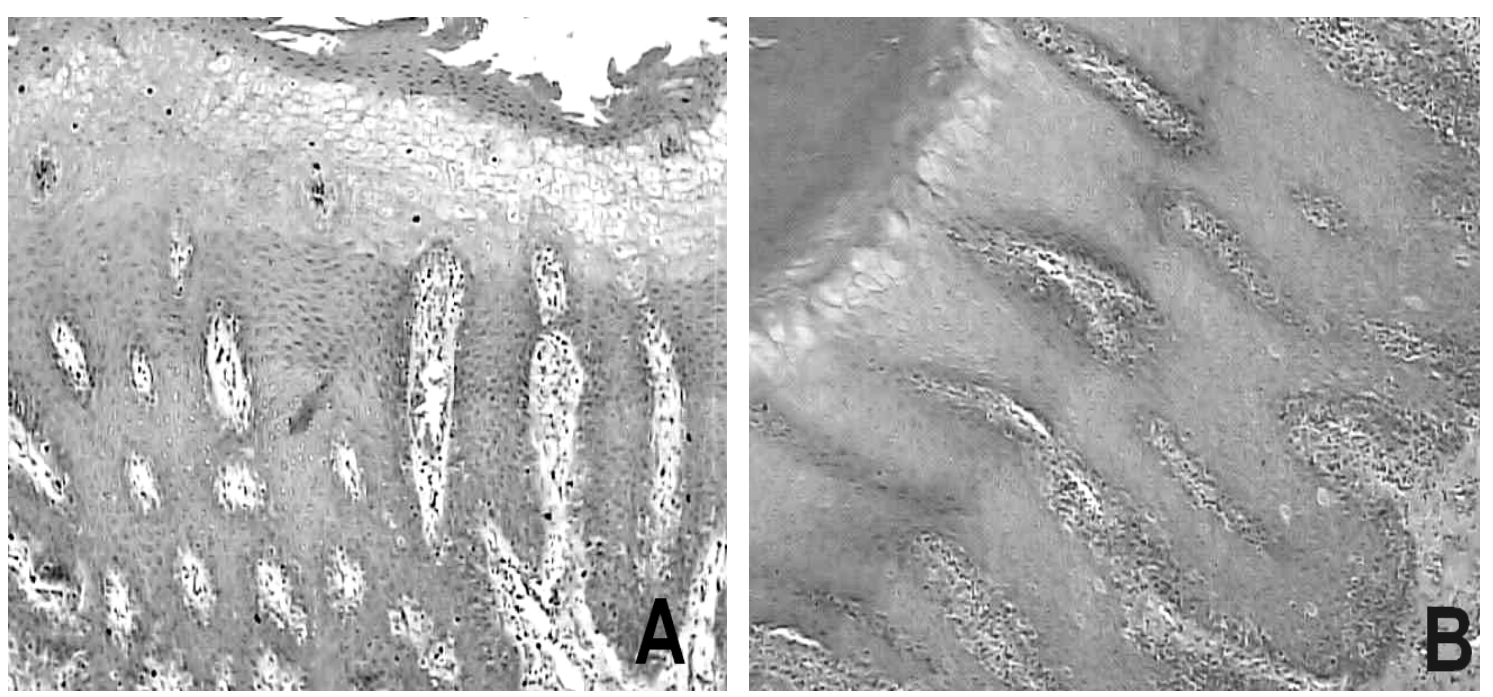

Figura 1. Fotomicrografia da pars esophagea, suíno. Alongamento de papilas epiteliais e paraqueratose (A e B). HE - 100X.

${ }^{1}$ Electroph. Doc. Analysis System 290, Kodak - New York, EUA. 
Os folículos linfoides estavam presentes na submucosa da pars esophagea de 54 (80,5\%) amostras, sendo que aquelas com até dois folículos por campo foram as mais frequentes $(52,2 \%)$ (Fig. 2B e Tab. 1).

A histopatologia revelou a presença de infiltrado inflamatório difuso tanto na lâmina própria quanto no epitélio estratificado. $\mathrm{Na}$ lâmina própria, observou-se infiltrado linfoplasmocitário em todas as amostras, infiltrado eosinofílico em $25(37,3 \%)$ e infiltrado neutrofílico em $16(23,8 \%)$. A graduação mais frequente foi a de grau 1 (Tab. 1). Na camada epitelial, a inflamação de intensidade grau 0 foi constatada em todas as amostras, e infiltrados focais de neutrófilos (micropústulas) estavam presentes

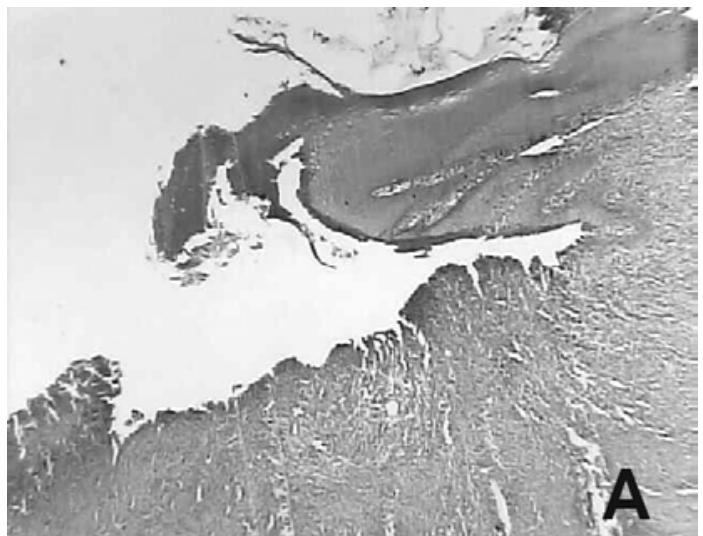

em $10(14,9 \%)$ amostras. Em oito animais, constatou-se a presença de bacilos na superfície epitelial.

Quarenta e sete amostras (70,1\%) apresentaram resultado positivo na PCR para o gênero Helicobacter (Fig. 3 e Tab. 1). A frequência e a classificação histológica das alterações observadas, distribuídas de acordo com a presença de Helicobacter spp., são apresentadas na Tab. 1. Degeneração epitelial discreta foi observada em 40 (59,7\%) estômagos, e $33(82,5 \%)$ dessas amostras foram positivas pela PCR. A análise estatística revelou diferença significativa entre a degeneração epitelial e a presença de Helicobacter spp. $(\mathrm{P}=0,003)$.

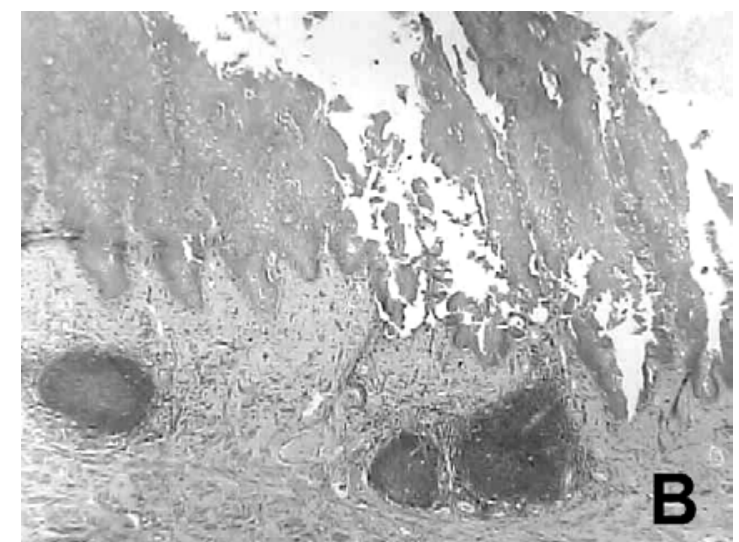

Figura 2. Fotomicrografia de pars esophagea, suíno. Úlcera acompanhada de intenso infiltrado inflamatório mononuclear. Há região íntegra de epitélio apresentando paraqueratose grave (A) e proliferação de folículos linfoides em submucosa e erosão epitelial (B). HE - 100X.

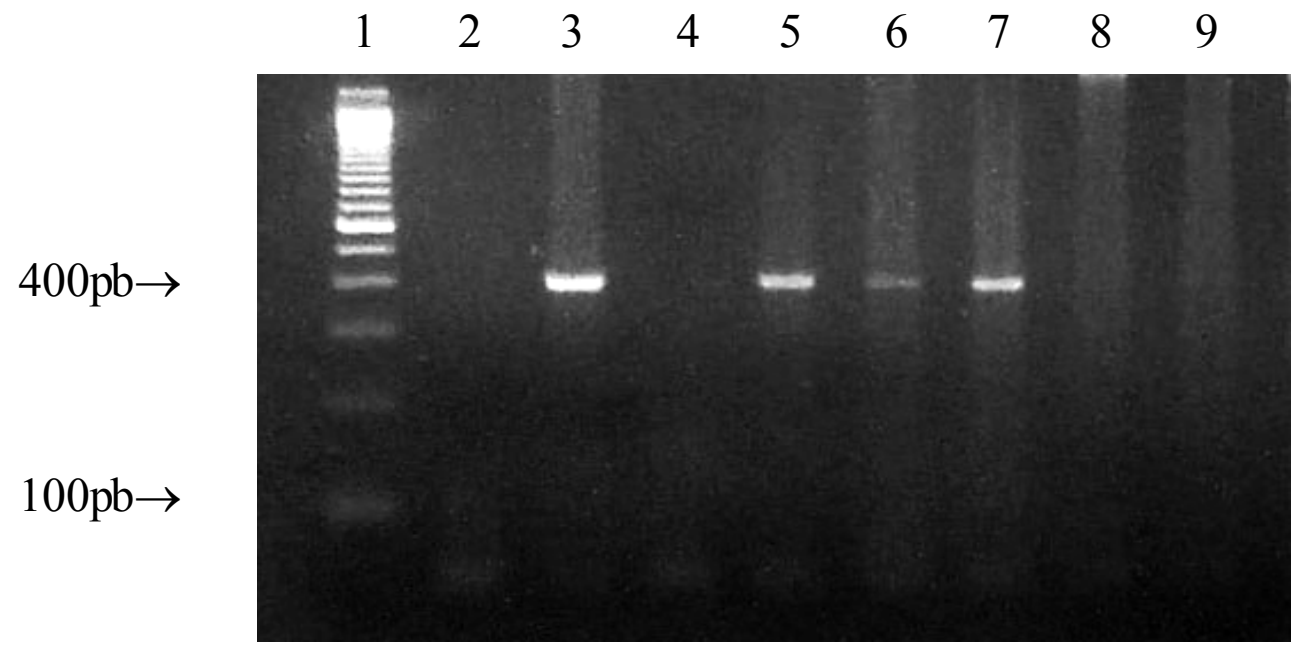

Figura 3. Eletroforese em gel de agarose a $2 \%$ com brometo de etídeo da PCR para Helicobacter spp. (400 pb). Canaleta 1: padrão de tamanho molecular de 100 pares de base; 2: controle negativo da reação; 3: controle positivo da reação; 4: controle negativo da extração. 5 a 9 amostras de estômagos de suínos. Positivos: 5, 6 e 7 . Negativos: 8 e 9. 
Tabela 1. Distribuição das alterações histológicas na pars esophagea de acordo com a identificação de Helicobacter spp. pela PCR em suínos em idade de abate

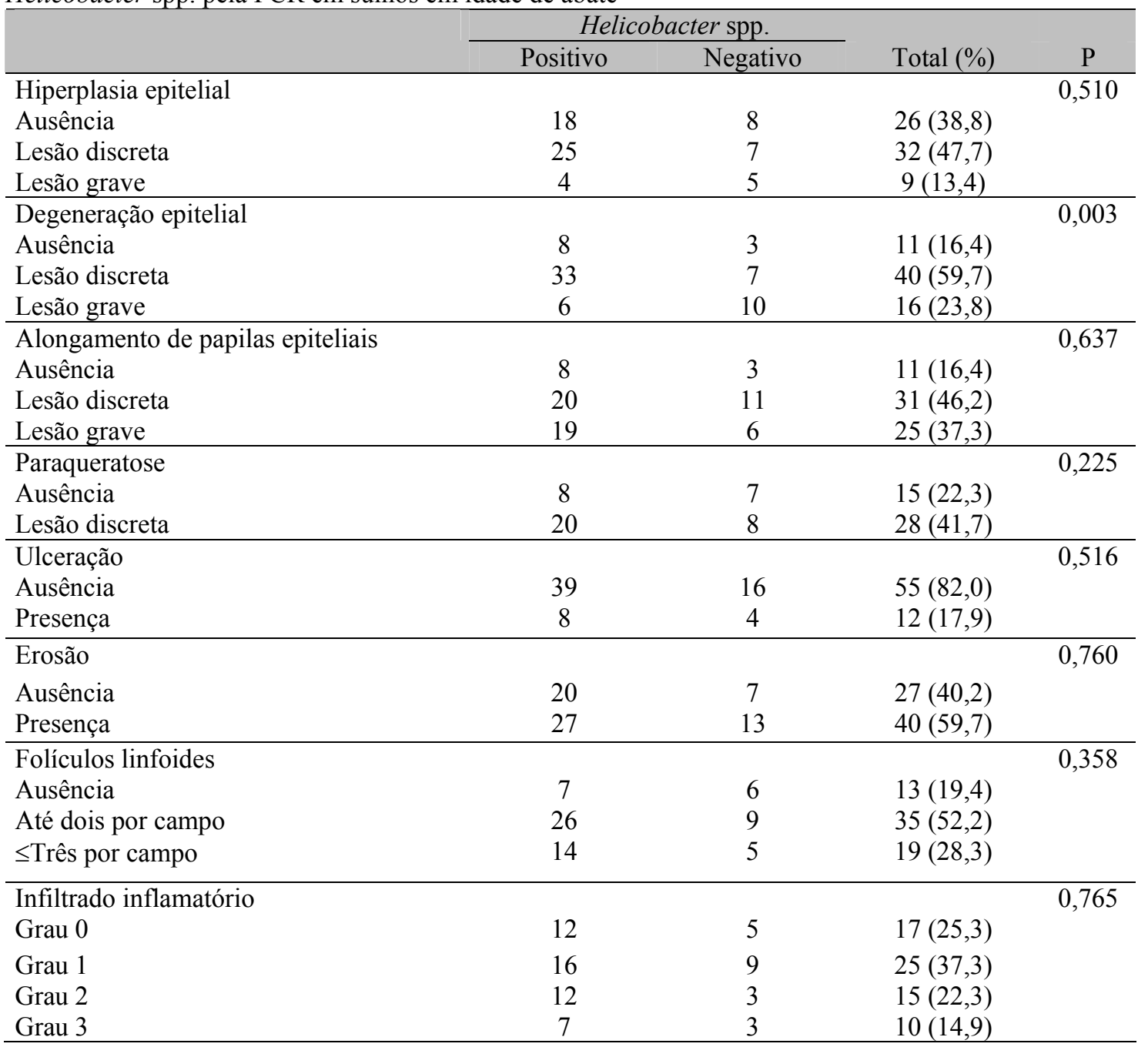

A erosão foi observada em $27(40,2 \%)$ amostras positivas na PCR. A frequência de ulceração da pars esophagea foi de $11,9 \%(\mathrm{n}=8)$ em amostras em que o diagnóstico de Helicobacter spp. foi positivo. Animais que não tinham ulceração e eram Helicobacter spp. positivo apresentaram frequência de $58,2 \%(n=39)$. Não houve diferença significativa entre as variáveis analisadas $(\mathrm{P}=0,516)$.

Quanto ao número de folículos linfoides, 54 $(80,5 \%)$ amostras apresentaram mais de um folículo linfoide por campo, sendo $40(74,1 \%)$ dessas amostras positivas pela PCR. Dezenove $(28,3 \%)$ amostras tiveram contagem de folículos igual ou superior a três por campo; dessas, 14 $(73,6 \%)$ foram positivas na PCR. Foi observado, ainda, que o infiltrado inflamatório difuso estava presente em maior número nas amostras positivas para Helicobacter spp., sem, contudo, haver significância entre essas variáveis.

\section{DISCUSSÃO}

No Brasil são poucos os relatos envolvendo a análise histológica de pars esophagea em suínos. Carvalho et al. (1999) observaram alterações histológicas, como paraqueratose, edema e degeneração, porém sem definir a frequência de tais alterações. Em outros países, as lesões descritas nessa região estomacal dos suínos foram necrose epitelial, infiltrado neutrofílico e eosinofílico e hiperplasia linfoide (Muggenburg et al., 1964; O’Brien, 1993; Szeredi et al., 2005). A frequência de alterações histológicas na pars 
esophagea encontrada neste estudo e os resultados obtidos em outras investigações com análise macroscópica sugerem que essas lesões são muito frequentes no rebanho suíno brasileiro (Monticelli et al., 1995; Carvalho et al., 1999; Yamasaki et al., 2006).

A taxa de infecção $(70,1 \%)$ por Helicobacter spp. nas amostras analisadas foi similar às observadas por Cantet et al. (1999) e Young et al. (2001), que também, por meio da PCR, encontraram 80 e $63,8 \%$ de amostras positivas, respectivamente. Grasso et al. (1996) e Melnichouk et al. (1999), ao utilizarem somente a histopatologia como método diagnóstico para Helicobacter spp., verificaram apenas 9,4 e $32,6 \%$ de amostras positivas. A maior sensibilidade da PCR na identificação de Helicobacter spp. em comparação ao exame histopatológico e ao teste da urease também já foi descrita por outros autores (De Groote et al., 2000; Park et al., 2003, 2004).

Em suínos, a associação entre lesões gástricas e a infecção por Helicobacter spp. ainda é controversa. Diversos experimentos confirmam a estreita relação entre o estabelecimento das lesões na pars esophagea e a presença de Helicobacter spp. (Queiroz et al., 1990; De Groote et al., 2000; Mall et al., 2004). Entretanto, Szeredi et al. (2005), ao avaliarem 89 suínos em idade de abate, verificaram associação entre a presença de Helicobacter spp. somente na região glandular do estômago e em alterações específicas como dilatação glandular, abscessos glandulares e degeneração epitelial.

Krakowka et al. (2005) relataram que, em suínos inoculados com Helicobacter heilmannii, não foram observadas lesões microscópicas significativas na pars esophagea ou região glandular, enquanto os suínos inoculados com o H. pylori - like de origem suína apresentaram doença gástrica grave. Atualmente, admite-se que a espécie $H$. heilmannii é característica de suínos (Park et al., 2003) e que a patogenia das lesões gástricas está relacionada à espécie infectante.

No presente estudo, foi possível observar que alterações histológicas, como erosão e ulceração, foram mais frequentes em animais com infecção por Helicobacter spp. Observou-se que a degeneração epitelial foi significativamente maior em animais positivos na PCR. Essa alteração celular é um processo reversível que, com a persistência da injúria, pode evoluir para a morte celular. Dessa forma, a degeneração epitelial pode ser considerada uma lesão préulcerogênica. Proteínas secretadas por $H$. pylori como a vacA e a cagA induzem à formação de poros nas membranas celulares e vacuolização citoplasmática, atuando, ainda, na modulação da apoptose (Fischer et al., 2004). Utriainen e Hanninen (1998) identificaram genes vacA em amostras de estômagos de suínos, sem, no entanto, analisarem a relação entre o gene e as lesões da mucosa

Kowalczyk (1969) e Guise et al. (1997) relataram que o impacto econômico das doenças gástricas na suinocultura se dá pela taxa de mortalidade associada à forma hemorrágica aguda em matrizes, ressaltando a importância de doenças gástricas graves em suínos de idade superior à de animais de abate. Desse modo, é possível supor que, em animais com maior tempo de vida, possam ocorrer lesões consideradas préulcerogênicas causadas pela infecção por Helicobacter spp. e que, com o tempo, essa injúria constante leve as células epiteliais da degeneração à necrose celular e, consequentemente, à formação de úlceras na pars esophagea.

Todas as alterações observadas são formas de reação epitelial a uma injúria. $\mathrm{O}$ alongamento das papilas e a paraqueratose foram observados em $56(83,5 \%)$ e $52(77,6 \%)$ das amostras analisadas, respectivamente. As duas alterações ocorreram no mesmo número $(\mathrm{n}=39)$ de amostras positivas na PCR. Esse número representa 69,6\% das amostras com alongamento de papilas e $75 \%$ das amostras com paraqueratose. Dessa forma, apesar de a relação entre as lesões histológicas e a presença de Helicobacter spp. não ser estatisticamente significativa, algumas alterações mostraram-se mais frequentes em animais positivos na PCR em comparação aos negativos.

Ernst et al. (2006) relataram a relação entre a hiperplasia de folículos linfoides ou infiltrados inflamatórios difusos e Helicobacter pylori em seres humanos. Em suínos, Krakowka et al. (2005) observaram que os animais infectados experimentalmente desenvolveram quadro inflamatório da mucosa gástrica com infiltrado inflamatório mononuclear difuso e formação de 
agregados linfoides em lâmina própria, tanto na região aglandular quanto na glandular. Embaye et al. (1990), ao analisarem estômagos de suínos de 10 a 22 semanas de idade, constataram a presença de infiltrado inflamatório discreto em pars esophagea que apresentavam aspecto macroscópico normal.

Quanto à presença de folículos linfoides, 35 $(52,2 \%)$ amostras que apresentaram um ou mais folículos foram positivas para helicobactérias, enquanto nas amostras negativas apenas 15 $(22,3 \%)$ apresentavam folículos. Em 40 (59,7\%) observaram-se de um a dois folículos por campo; dessas, $28(70,0 \%)$ eram positivas para Helicobacter spp. A frequência de amostras com proliferação de folículos na pars esophagea não diferiu entre os grupos positivos e negativos para Helicobacter spp. $(\mathrm{P}=0,225)$.

Os resultados permitem afirmar que as alterações histológicas na mucosa da região aglandular de suínos em idade de abate no estado do Paraná ocorrem com frequência elevada. Embaye et al. (1990) também observaram alta ocorrência de alterações degenerativas e erosivas nessa região do estômago de suínos. Esses autores sugeriram que as lesões são consequências de uma dieta rica em carboidratos fermentáveis, com partículas finas, e da presença de lactobacilos capazes de produzir ácido no estômago.

Os resultados conflitantes a respeito das lesões gástricas em suínos justificam estudos mais minuciosos para o estabelecimento da patogenia de tais alterações, que podem acarretar prejuízos econômicos consideráveis para a produção suinícola (O’Brien, 1993). As alterações histológicas, como gastrites e câncer gástrico, em consequência da infecção por Helicobacter pylori no homem (Ernst et al., 2006), justificam a realização de estudos mais abrangentes que possibilitem o prévio conhecimento das espécies de Helicobacter em suínos e seus possíveis fatores de patogenicidade. No Brasil ainda são escassos os relatos que identificam as espécies de Helicobacter no plantel suíno, inexistindo estudos que identifiquem fatores de patogenicidade da bactéria.

O presente estudo permite afirmar que a degeneração epitelial é uma alteração associada à infecção por Helicobacter spp. e que, para as outras alterações histológicas, as amostras positivas para Helicobacter spp. apresentam alterações com maior frequência que as amostras negativas. Estes resultados sugerem que a bactéria Helicobacter pode ter importante função no estabelecimento de lesões gástricas precoces, aumentando a possibilidade de agravamento de tais lesões com o avanço da idade dos suínos.

\section{REFERÊNCIAS BIBLIOGRÁFICAS}

BARBOSA, A.J.A.; SILVA, J.C.P.; NOGUEIRA, M.M.F. et al. Higher incidence of Gastropirillum sp. in swine with gastric ulcer of the pars oesophagea. Vet. Pathol., v.32, p.134-139, 1995.

BOOM, R.; SOL, C.J.A.; SALIMANS, M.M.M. et al. Rapid and simple method for purification of nucleic acids. J. Clin. Microbiol., v.28, p.495-503, 1990.

BRENNER, H.; ARNDT, V.; STEGMAIER, C. et al. Is Helicobacter pylori infection a necessary condition for noncardia gastric cancer? Am. J. Epidemiol., v.159, p.252-258, 2004.

CANTET, F.; MAGRAS, C.; MARAIS, A. et al. Helicobacter species colonizing pig stomach: molecular characterization and determination of prevalence. Environ. Microbiol., v.65, p.4672-4676, 1999.

CARVALHO, L.F.O.S.; OLIVEIRA, C.J.B.; MARTINEZ, P.A.O. et al. Frequência de lesões gástricas em suínos destinados ao abate na região de Ribeirão Preto, SP. Arq. Bras. Med. Vet. Zootec., v.51, p.223-227, 1999.

DE GROOTE, D.; DUCATELLE, R.; VAN DOORN, L.J. et al. Detecion of "Candidatus Helicobacter suis" in gastric samples of pig by PCR: comparison with other invasive diagnostic techniques. J. Clin. Microbiol., v.38, p.1131-1135, 2000.

EMBAYE, H.; THOMLINSON, J.R.; LAWRENCE, T.L.J. Histopathology of oesophagogastric lesions in pigs. J. Comp. Pathol., v.103, p.253-264, 1990.

ERNST, P. B.; PEURA, D. A.; CROWE, S. E. The translation of Helicobacter pylori basic research to patient care. Gastroenterology, v.206, p.130-188, 2006.

FISCHER, W.; GEBERT, B.; HAAS, R. Novel activities of Helicobacter pylori vacuolating cytotoxin: from epithelial cells towards the immune system. Int. J. Med. Microbiol., v.293, p.539-547, 2004.

FOX, J.G.; LEE, A. The role of Helicobacter species in newly recognized gastrointestinal tract diseases of animals. Lab. Anim. Sci., v.47, p.222-255, 1997.

GRASSO, G.M.; RIPABELLI, G.; SAMMARCO, M. et al. Prevalence of Helicobacter-like organisms in porcine gastric mucosa. A study of swine slaughtered 
in Italy. Comp. Immunol. Microbiol. Infect. Dis., v.19, p.213-217, 1996.

GUISE, H.J.; CARLYLE, W.W.H.; PENNY, R.H.C. Gastric ulcers in finishing pigs: their prevalence and failure to influence growth rate. Vet. Rec., v.141, p.563-566, 1997.

KOWALCYZK, T. Etiologic factors of gastric ulcers in swine. Am. J. Vet. Res., v.30, p.393-400, 1969.

KRAKOWKA, S.; RINGS, D.M.; ELLIS, J.A. Experimental induction of bacterial gastritis and gastric ulcer disease in gnotobiotic swine inoculated with porcine Helicobacter-like species. Am. J. Vet. Res., v.66, p.945-952, 2005.

MALL, A.S.; SULEMAN, N.; TAYLOR, K. et al. The relationship Helicobacter heilmannii infection to the mucosal changes in abattoir and laboratory pig stomach. Surg. Today, v.34, p.943-949, 2004.

MARSHAL, B.J.; WARREN, J.R. Unidentified curved bacilli in the stomach of patients with gastritis and peptic ulceration. Lancet, v.1, p.1311-1314, 1984.

MELNICHOUK, S.I.; FRIENDSHIP, R.M.; DEWEY, C.E. et al. Helicobacter-like organisms in the stomach of pigs with and without gastric ulceration. Swine Health Prod., v.7, p.201-205, 1999.

MONTICELLI, C.J.; MENTEN, J.F.M.; ZANOTTO, D.L. Efeito da granulometria do milho, da área por animal e do sexo sobre lesões gástricas de suínos. In: CONGRESSO BRASILEIRO DE VETERINÁRIOS ESPECIALISTAS EM SUÍNOS, Blumenau. Anais... Blumenau: ABRAVES, 1995. p.165. (Resumo).

MORÉS, N.; SOBESTIANSKY, J.; LOPES, A. Avaliação patológica de suínos no abate: Manual de identificação. Brasília, DF: EMBRAPA, 2000. p.2224.

MOUTINHO, F.Q; THOMASSIAN, A.; WATANABE, M.J. et al. Prevalência de helicobactérias e alterações na mucosa gástrica de cães saudáveis. Arq. Bras. Med. Vet. Zootec., v.59, p.10801083, 2007.

MUGGENBURG, B.A.; REESE, B.S.; KOWALSKY, M.S. et al. Survey of the prevalence of gastric ulcers in swine. Am. J. Vet. Res., v.25, p.1673-1678, 1964.

O'BRIEN, J.J. Gastric ulcers. In: LEMAN, A.D.; STRAW, B.E.; MENGELING, W.L. et al. (Ed.). Diseases of swine. 7.ed. Ames: Iowa State University, 1993. p.680-691.
PARK, J.-H.; HONG, J.J.; PARK, J.-H. Experimental infection of mice with tightly coiled spiral bacteria ("Candidatus Helicobacter suis") originating from the pig stomach. J. Comp. Pathol., v.129, p.154-160, 2003.

PARK, J.-H.; SEOK, S.-H.; CHO, S.-A. et al. The high prevalence of Helicobacter sp. in porcine pyloric mucosa and its histopathological and molecular characteristics. Vet. Microbiol., v.104, p.219-225, 2004.

QUEIROZ, D.M.M.; ROCHA, G.F.; MENDES, E.N. et al. A spiral microorganism in the stomach of pigs. Vet. Microbiol., v.24, p.199-204, 1990.

QUEIROZ, D.M.M.; ROCHA, G.F.; MENDES, E.N. et al. Association between Helicobacter and gastric ulcer disease of the pars esophagea in swine. Gastroenterology, v.27, p.111-119, 1996.

RILEY, L.K.; FRANKLIN, C.L.; HOOK, R.R. et al. Identification of murine helicobacters by PCR and restricition enzyme analises. J. Clin. Microbiol., v.34, p.942-946, 1996.

ROOSENDAAL, R.; VOS, J.H.; ROUMEN, T. et al. Slaughter pigs are commonly infected by closely related but distinct gastric ulcerative lesion-inducing gastropirilla. J. Clin. Microbiol., v.38, p.2661-2664, 2000.

SZEREDI, L.; PALKOVICS, G.; SOLYMOSI, N. et al. Study on the role of gastric Helicobacter infection in gross pathological and histological lesions of the stomach in finishing pigs. Acta Vet Hung., v.53, p.371-383, 2005.

UTRIAINEN, M.; HÄNNINEN, M.L. Detection of Helicobacter-like bacteria in porcine gastric biopsy samples by amplification of $16 \mathrm{~S}$ rRNA, ureB, vacA and cagA genes by PCR. Vet. Res. Commun., v.22, p.373-383. 1998.

YAMASAKI, L.; ASSIS, F.M.S.; ROSSETO, V.J.V. et al.Lesões gástricas em suínos: ocorrência e relação com o gênero, peso ao abate e presença de Helicobacter spp. Semina: Cienc. Agrar., v.27, p.463470, 2006.

YOUNG, Y.K.; HAN, J.H.; JOO, H.S. Identification of novel Helicobacter species in pig stomachs by PCR and partial sequencing. J. Clin. Microbiol., v.39, p.3311-3315, 2001. 